\title{
Mitochondrial discrimination of honeybees (Apis mellifera) of Sudan*
}

\author{
Mogbel A.A. EL-NIWEIRI, Robin F.A. MORITZ \\ Institut für Biologie, Martin-Luther-Universität of Halle-Wittenberg, Hoher Weg 4, 06099 Halle/Saale, Germany
}

Received 13 December 2007 - Revised 15 May 2008 - Accepted 30 May 2008

\begin{abstract}
Sudanese honeybee populations are surrounded by a suite of various subspecies with different mitochondrial haplotypes, including the O-lineage in the north (Egypt), the Y-lineage in the east (Ethiopia) and the A-lineage in the south and west. Using Dra I analyses and the partial sequence of the tRNAleu COII region of 75 sampled colonies throughout Sudan, we never found the Y-lineage in Sudanese honeybees but instead seven different haplotypes from the A-, O-, and C-lineage $\left(\mathrm{A}_{1}, \mathrm{~A}_{4}, \mathrm{~A}_{8}, \mathrm{~A}_{13}, \mathrm{O}_{1}{ }^{\prime}, \mathrm{O}_{1}\right.$ and $\left.\mathrm{C}_{2}\right)$ suggesting that the Y-lineage is not common to Sudan. The mitochondrial haplotypes co-segregated with the highly diverse ecosystems in Sudan. Honeybees of the wet savannah and forest ecosystems showed the A-lineage, identical to A. m. adansonii and A. $m$. scutellata. The honeybees in the desert, semi desert, and dry savannah of Sudan have the O-lineage, similar to A. m. lamarckii and A. m. syriaca. Haplotype $\mathrm{C}_{2}$ was found in apiaries with imported stock (A. m. carnica). This reclassification of the honeybees from Sudan has consequences for the interpretation of the biogeography of A. mellifera in the Maghreb and Mashriq regions.
\end{abstract}

\section{Apis mellifera jemenitica / subspcies / mitochondrial DNA / Sudan / biogeography}

\section{INTRODUCTION}

The Western honeybee, Apis mellifera L., comprises a vast number of endemic subspecies in Europe, Asia and Africa. North and North-East Africa appears to be a region with a particularly high honeybee diversity (Whitfield et al., 2006) and five different subspecies of Apis mellifera have been taxonomically recognized from this area (Engel, 1999): A. m. lamarckii (Cockerell, 1906) in Egypt; A. m. intermissa (Maa, 1953) and A. $m$. sahariensis (Baldensperger, 1932) in Morocco; A. m. litorea (Smith, 1961) and A. m. jemenitica (Ruttner, 1975) in eastern Africa. However, the honeybees of Sudan, a region bridging many of these areas, have been neither intensively nor systematically sampled. The classification of the honeybees' native to Sudan has therefore been controversial. Al-

Corresponding author: M.A.A. El-Niweiri, mogbel.elniweiri@zoologie.uni-halle.de

* Manuscript editor: Stefan Fuchs though initially the subspecies included $A$. m. nubica Ruttner (1975), A. m. sudanensis (El-Sarrag et al., 1992) and A. m. bandasii (Mogga, 1988), today only a single subspecies is recognized, A. m. jemenitica (Ruttner, 1988; Engel, 1999), because the various taxa did not form discrete and separate morphoclusters (Hepburn and Radloff, 1998).

Mitochondrial DNA (mtDNA) has also been used to classify honeybee subspecies (Cornuet and Garnery, 1991; Smith, 1991; Garnery et al., 1992; Moritz et al., 1994). In particular, mtDNA variance in the COICOII region has been extensively used to discriminate among the A. mellifera subspecies (Moritz et al., 1994, 1998; Garnery et al., 1995). Although the majority of African honeybees belong to a mitochondrial lineage termed "A" (Smith, 1991; Garnery et al., 1992, 1993; Arias and Sheppard, 1996., Franck et al., 2001) there is considerable mtDNA variability, particularly in the North East of the continent. The honeybees of North- and East Africa can 
be assigned to three different mtDNA lineages: A, O and Y. A. m. intermissa in Morocco and Algeria belong to the A lineage comprising eight different haplotypes $\left(A_{1}-A_{4}, A_{8}-A_{10}\right.$, $\left.A_{13}\right)$. Five haplotypes of the A-lineage have been reported for the neighbouring subspecies A. m. sahariensis $\left(\mathrm{A}_{1}, \mathrm{~A}_{3}, \mathrm{~A}_{4}, \mathrm{~A}_{8}\right.$, and $\left.\mathrm{A}_{9}\right)$ (Garnery et al., 1995). In Egypt A. m. lamarckii only carries the O-lineage haplotypes, whereas A. m. jemenitica from Ethiopia belongs to the Y-lineage detected by Franck et al. (2001). A. $m$. litorea from Somalia belongs to two different mtDNA lineages, $\mathrm{O}$ and A (Franck et al., 2001). As a result, Sudanese honeybee populations are surrounded by a suite of various lineages with the O-lineage in the north (Egypt) (Franck et al., 2001), the Y-lineage in the east (Ethiopia) and the A-lineage in the south and west (Franck et al., 2001). Given the vast size of the country and its highly diverse ecosystems spanning from deserts to tropical forests, one might expect considerable variability among the native honeybees of Sudan. If variable climatic conditions and ecosystems are important factors for natural selection shaping A. mellifera ecotypes and subspecies, it would be surprising to find only a single ecotype in the region. Since morphometrical analyses yielded no distinct morphoclusters (Hepburn and Radloff, 1998), we here focus on mtDNA variability of $A$. mellifera samples from Sudan as a tool for classification. We use the Dra I test of the COI-COII region in combination with sequence information to assign the biogeographic lineages of endemic honeybees. This data will also be an important base for developing coherent policies for the conservation of local honeybees in Sudan.

\section{MATERIALS AND METHODS}

\subsection{Sampling}

About 100 workers each from seventy five colonies were sampled from different localities in Sudan covering most diverse habitats, ranging from desert to tropical rainforest (Fig.1). Forty seven colonies were sampled in the wild and 28 colonies from three managed apiaries in Khartoum (2), Sinjah (6), and New Halfa (3) (Tab. I, Fig. 1). All sampled workers were preserved in $75 \%$ ethanol until

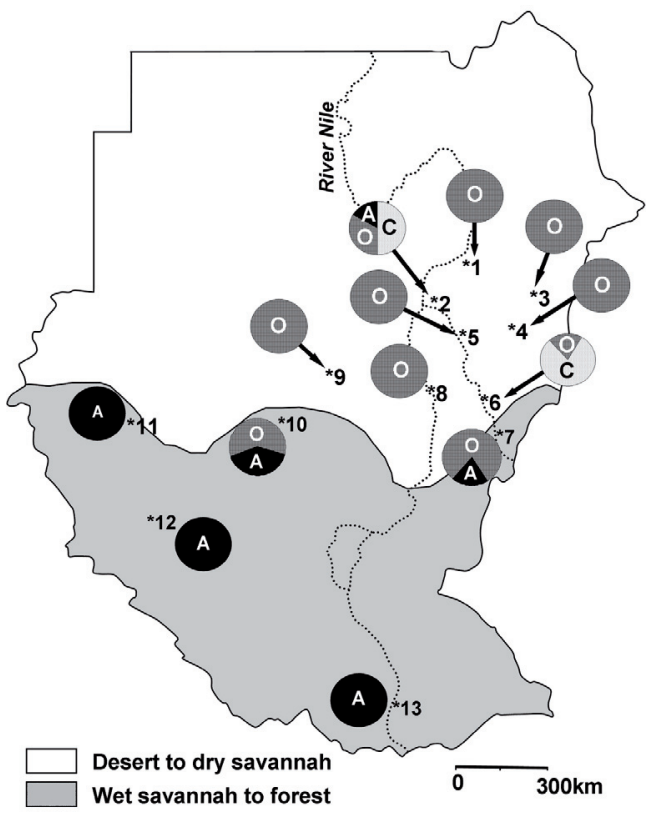

Figure 1. Vegetation zones of Sudan (El-Sarrag, 1977; Harrison and Jackson, 1958) and the distribution of COI-COII lineages at the sample locations (1 to 13). Pie charts indicate the frequencies of the mitochondrial lineages $\mathrm{A}, \mathrm{O}$, and $\mathrm{C}$ at each location. Managed colonies from apiaries at locations 2 and 6 had the non-native haplotype C. For more detailed haplotype information see Table I.

DNA extraction. The lower numbers of sampling locations (5) and sampled colonies $(n=18)$ in south and west Sudan compared to north and central Sudan (8 locations and 57 colonies) is due to severe sampling problems related to the Darfour war and the absence of any apiculture in these regions.

\subsection{DNA extraction}

Up to five worker bees per colony were subjected to mtDNA analysis. Workers were rinsed for two hours at room temperature and vacuumdried overnight (Garnery et al., 1993). Total DNA was extracted from legs using the Chelex extraction method (Walsh et al., 1991).

\subsection{PCR amplification and digestion}

The COI-COII region of the mtDNA was amplified with standard PCR techniques in a total volume 
Table I. Localities, coordinates, types and numbers of colonies, frequencies of haplotyps, ecological data and altitudes of sampling areas.

\begin{tabular}{|c|c|c|c|c|c|c|c|c|c|c|c|c|c|c|}
\hline & Location & North & East & Type & $\mathrm{n}$ & $\overline{A_{1}}$ & $\overline{\mathrm{A}_{4} \mathrm{~A}}$ & $\mathrm{~A}_{8} \mathrm{~A}_{1}$ & $\mathrm{O}_{1}$ & $\mathrm{O}_{1}^{\prime}$ & $\mathrm{C}_{2}$ & Habitat & $\begin{array}{c}\text { Precipitation } \\
\text { (mm/year) }\end{array}$ & Altitude \\
\hline 1 & Shendi & $16^{\circ} 42^{\prime}$ & $33^{\circ} 26^{\prime}$ & wild & 5 & & & & 3 & 2 & & desert & $25-74$ & $360 \mathrm{~m}$ \\
\hline 2 & Khartoum & $15^{\circ} 35^{\prime}$ & $32^{\circ} 32^{\prime}$ & apiary & 8 & & 1 & & 3 & & 4 & semi desert & $75-224$ & $377 \mathrm{~m}$ \\
\hline 3 & New Halfa & $15^{\circ} 20^{\prime}$ & $35^{\circ} 35^{\prime}$ & apiary & 10 & & & & 2 & 8 & & semi desert & $75-224$ & $459 \mathrm{~m}$ \\
\hline 4 & Al Faw & $14^{\circ} 9^{\prime}$ & $34^{\circ} 20^{\prime}$ & wild & 10 & & & & 3 & 7 & & dry savannah & $225-274$ & $439 \mathrm{~m}$ \\
\hline 5 & Wad Madani & $14^{\circ} 24^{\prime}$ & $33^{\circ} 32^{\prime}$ & wild & 5 & & & & 5 & & & dry savannah & $225-274$ & $414 \mathrm{~m}$ \\
\hline 6 & Sinjah & $13^{\circ} 9^{\prime}$ & $33^{\circ} 56^{\prime}$ & apiary & 10 & & & & & 2 & 8 & dry savannah & $375-474$ & $397 \mathrm{~m}$ \\
\hline 7 & Dmazin & $11^{\circ} 46^{\prime}$ & $34^{\circ} 21^{\prime}$ & wild & 4 & & & 1 & 1 & 2 & & wet savannah & $475-724$ & $487 \mathrm{~m}$ \\
\hline 8 & Kosti & $13^{\circ} 10^{\prime}$ & $32^{\circ} 40^{\prime}$ & wild & 5 & & & & 5 & & & dry savannah & $225-274$ & $380 \mathrm{~m}$ \\
\hline 9 & Umm & $12^{\circ} 54^{\prime}$ & $31^{\circ} 13^{\prime}$ & wild & 4 & & & & 4 & & & dry savannah & $375-474$ & $458 \mathrm{~m}$ \\
\hline & Ruwabah & & & & & & & & & & & & & \\
\hline 10 & Nyala & $12^{\circ} 3^{\prime}$ & $24^{\circ} 53^{\prime}$ & wild & 2 & 2 & & & & & & wet savannah & $475-724$ & $686 \mathrm{~m}$ \\
\hline 11 & Hujaylij & $11^{\circ} 59^{\prime}$ & $27^{\circ} 52^{\prime}$ & wild & 5 & & 1 & 1 & 3 & & & wet savannah & $725-974$ & $467 \mathrm{~m}$ \\
\hline 12 & Raga & $8^{\circ} 28^{\prime}$ & $25^{\circ} 41^{\prime}$ & wild & 3 & 3 & & & & & & wet savannah & $725-974$ & $603 \mathrm{~m}$ \\
\hline 13 & Juba & $4^{\circ} 51^{\prime}$ & $31^{\circ} 37^{\prime}$ & wild & 4 & 4 & & & & & & forest & $975-1474$ & $550 \mathrm{~m}$ \\
\hline
\end{tabular}

of $30 \mu \mathrm{L}$ with $1 \times$ Taq buffer, $2 \mathrm{mM} \mathrm{MgCl}, 0.2 \mathrm{mM}$ of each dNTP, $0.15 \mu \mathrm{M}$ of primers E2 and H2 (Garnery et al., 1992), and $1 \mathrm{U}$ Taq-polymerase. The PCR program was as follows: 5 min initial denaturation at $96{ }^{\circ} \mathrm{C}, 30$ cycles at $95{ }^{\circ} \mathrm{C}$ for $0.5 \mathrm{~min}$, $1.5 \mathrm{~min}$ at $50{ }^{\circ} \mathrm{C}$, and $1.5 \mathrm{~min}$ at $72{ }^{\circ} \mathrm{C}$, with a final extension of $10 \mathrm{~min}$ at $72{ }^{\circ} \mathrm{C}$. Five $\mu \mathrm{L}$ of the PCR product were electrophoresed in a $1.5 \%$ agarose gel for size determination, and $20 \mu \mathrm{L}$ were treated with the restriction enzyme $\operatorname{Dra} \mathrm{I}(0.5 \mathrm{U})$ at $37{ }^{\circ} \mathrm{C}$ for 4-12 h. Restriction fragments were separated on 8$10 \%$ acrylamide gels and stained with ethidium bromide.

\subsection{DNA purification and sequencing}

Haplotypes which were difficult to interpret based on restriction analyses alone were confirmed by sequencing both strands of the intergenic region including the noncoding region and the 5'end of the COII gene (Franck et al., 2000a, 2001). PCR Purification of the amplified DNA fragments was achieved using the Pench Protocol for Microcentrifuge (QIAGEN). The purified PCR product was sequenced using the same primers as those in the PCR reactions and BigDye Terminator Kit (v3.1) by using the cycle sequencing technology (dideoxy chain termination / cycle sequencing) on
ABI 3730XL sequencing machines (MWG). Multiple alignments were done by using the online version of multiple alignment program for amino acid or nucleotide sequences (MAFFT version 6).

\section{RESULTS}

\subsection{Haplotypes}

All samples showed the typical PCRproducts ranging between $571 \mathrm{bp}$ and $838 \mathrm{bp}$ corresponding to the predicted $\mathrm{P}_{o}$ and $\mathrm{Q}$ repeat pattern in the target region. Restriction with the enzyme Dra I yielded seven different restriction patterns (Fig. 2) matching the haplotypes $\mathrm{A}_{1}, \mathrm{~A}_{4}, \mathrm{~A}_{8}, \mathrm{~A}_{13}, \mathrm{O}_{1}, \mathrm{O}_{1}$ ' and $\mathrm{C}_{2}$ (Garnery et al., 1993, 1995; Franck et al., 1998, 2000a, 2000b, 2001). Figure 2 shows acrylamide gels with the types and fragment patterns of the samples in wild populations (A) and the apiaries (B). Five haplotypes: $\mathrm{A}_{1}, \mathrm{~A}_{4}$, $\mathrm{O}_{1}, \mathrm{O}_{1}$ ' and $\mathrm{C}_{2}$ were confirmed by sequence analyses. 
(B)

(A)

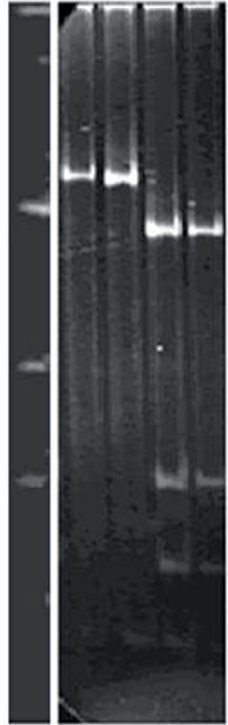

A4 A8 A8 0101

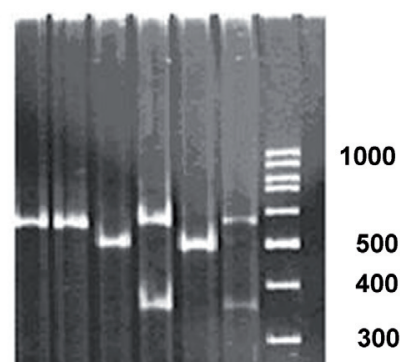

250

200

150

100

50

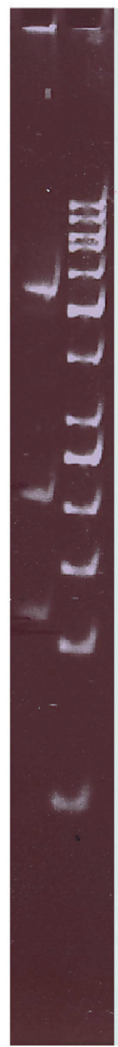

A4 M O1'C2 C2 M O1 M
1000

500

400

300

250

200

150

100

50

APIARY COLONIES

WILD COLONIES

Figure 2. MtDNA fragment patterns of honey bees of Sudan in a $10 \%$ acrylamide gel after digestion with the enzyme DraI. Six different restriction patterns were found corresponding to the haplotypes: $\mathrm{A}_{1}$ (47 bp; 108 bp; 483 bp), $\mathrm{A}_{4}\left(47 \mathrm{bp} ; 108\right.$ bp; 193 bp; 483 bp), A $\left(47\right.$ bp; 591 bp), $\mathrm{A}_{13}$ (47 bp; 310 bp; 483 bp), $\mathrm{O}_{1}$ (47 bp; 67 bp; 108 bp; 420 bp), O ${ }_{1}^{\prime}\left(47\right.$ bp; 67 bp; 67 bp; 108 bp; 129 bp; 420 bp), $\mathrm{C}_{2}$ (47 bp; 64 bp; $420 \mathrm{bp}$ ). The haplotypes $\mathrm{A}_{1}, \mathrm{~A}_{4}, \mathrm{O}_{1}, \mathrm{O}_{1}$ ' and $\mathrm{C}_{2}$ were confirmed with sequencing. $\mathrm{M}=$ weight marker (100 bp ladder). The occasional mismatch artefacts of the observed restriction fragment pattern with the expected ones were confirmed by sequencing the PCR products.

\subsection{Spatial distribution of haplotypes}

The distribution of haplotypes per sample location is given in Table I. whereas the distribution of lineages per sample location is given in Figure 1. The honeybees sampled in wild colonies either belonged to the $\mathrm{A}$ or the $\mathrm{O}$ lineage. The $\mathrm{O}_{1}$ haplotype was present in all the surveyed localities except South west (11) and
South Sudan $(12,13)$. Particularly high $\mathrm{O}_{1}$ frequencies were observed in central Sudan and along the northern part of the Nile valley (1, $2,3,5,9)$, whereas the $\mathrm{O}_{1}$ ' haplotype was frequent in east Sudan $(3,4,6,7)$. The $\mathrm{A}_{4}$ and $\mathrm{A}_{1}$ haplotypes were frequent in west $(10,11)$ and south Sudan $(12,13)$ States. The haplotypes $A_{8}$ and $A_{13}$ are restricted to the southwest (10) and south-east (7) respectively. Only 
the colonies sampled on commercial apiaries $(2,6)$ included the non-native haplotype $C_{2}$ in addition to the native types.

There was a clear co-segregation of lineages and ecosystems. Honeybees of the wet savannahs and forest ecosystems all showed the A lineage, which is typical for A. m. scutellata and $A$. $m$. adansonii. In contrast, all samples from wild colonies in desert, semi-desert and dry savannah areas had the $\mathrm{O}$ lineage similar to A. m. lamarckii and A. m. syriaca. Mixed populations with $\mathrm{A}$ and $\mathrm{O}$ lineages were found in the transitional zones between wet and dry ecosystems and on the commercial apiary in Khartoum (2).

\section{DISCUSSION}

Clearly, we did not find any Sudanese honeybees that belonged to the $\mathrm{Y}$ lineage. This does not exclude that they might exist in nonsampled regions, but it does suggest that this lineage may be rare at best in Sudan. The high frequency of the O lineage in Sudan shows that a third lineage of Apis mellifera mtDNA is endemic to north-eastern Africa. Given this high mtDNA diversity and three lineage branches radiating from this region, our results support Ruttner et al.'s (1978) theory that north-eastern Africa and the Near East (Mashriq) might be a centre of origin of $A$. mellifera, which then spread north and south. They proposed that the species invaded Africa and Europe in three distinct branches, a South and Central African branch (A), a North African and West European branch $(\mathrm{M})$ and a North Mediterranean branch (C). This classification was further refined by adding the fourth biogeographic branch, $\mathrm{O}$, including the Near- and MiddleEastern subspecies (Ruttner, 1988) and later confirmed by mtDNA data (Smith and Brown, 1988; Garnery et al., 1992, 1993; Arias and Sheppard, 1996; Franck et al., 2000b; Franck et al., 2001).

We only found honeybees carrying A lineage haplotypes in the southern and south western parts of Sudan. According to Franck et al. (2001), the lineage $\mathrm{A}$ is composed of three sublineages; the first group, $A_{I},\left(A_{1}-A_{4}\right.$, $A_{6}, A_{12}, A_{13}, A_{19}$, and $\left.A_{24}-A_{27}\right)$ is endemic to most of Africa south of the Sahara. A second group, $\mathrm{A}_{\mathrm{II}}$, is characterized by haplotypes $\mathrm{A}_{8}$, $\mathrm{A}_{10}$, corresponding to A. $m$. sahariensis and $A$. $m$. intermissa from the Maghreb countries in Northern Africa. The third sublineage is characterized by haplotypes with the $\mathrm{P}_{1}$ sequence (group $\mathrm{A}_{\mathrm{III}}$ ) typical to A. m. iberiensis populations in Portugal and the Canary Islands. In our samples we found group $\mathrm{A}_{\mathrm{I}}$ haplotypes including $A_{1}, A_{4}, A_{13}$ and the $A_{8}$ haplotype belonging to the $A_{I I}$ group. The high frequency of group $A_{I}$ haplotypes in the west and south are in line with Franck et al. (2001), who report on a progressive decline of haplotype $\mathrm{A}_{1}$ frequencies from Guinea towards south-eastern Africa to be eventually replaced by haplotype $\mathrm{A}_{4}$ in $A$. m. monticola, A.m. scutellata and A. m. capensis.

Haplotypes $\mathrm{A}_{8}$ and $\mathrm{A}_{13}$ are typical of $A . m$. intermissa in Northern Africa (Garnery et al., 1995; Franck et al., 2001). We found these types in two wild colonies, in an area lacking any beekeeping activities. Since apiculture had no impact on these populations, the bees must have come there by natural means. Although these were only single colonies, our sampling was coarse and population frequencies may actually be considerably high. We cannot exclude that the occurrence of these haplotypes in Sudan may reflect ancient migration processes during the Middle Holocene ( 8000 years BP) from northern Africa into Sudan or the opposite (Gasse et al., 1990; Hooghiemstra et al., 1992; Ritchie, 1994) when the Sahara was a savannah-type habitat. The long range seasonal migrations typical of African honeybees of the savannahs may have facilitated the spread of honeybees across the now desert regions. A similar population admixture is also observed in northern Africa, where group $A_{I}$ haplotypes are found together with group $A_{I I}$ populations (Franck et al., 2001).

Honeybees in the highlands of Ethiopia and Kenya are morphometrically (Amssalu et al., 2004) and genetically (Meixner et al., 2000) different from honeybees in the lowland and savannah. If the Y lineage is typical to the mountain highland populations of Ethiopia, the lack of this type in Sudan may be due to the low altitudes. Sudan is mostly flat land with a mean altitude of $500 \mathrm{~m}$, and 
hence one would not expect any ecotypes typical of a highland habitat. Because Sudan lacks major geographical barriers separating honeybee populations, the differences in climate and vegetation seem to be the major cause of honeybee subspecies diversification (Potts and Behrensmeyer, 1992). Climatically there are four major zones in Sudan (van Chi-Bonnardel, 1973; Walter, 1976; Rudloff, 1981): hot desert, subdesert or Sahel, dry tropical and wet tropical. Correspondingly, the vegetation of Sudan has been classified into different types from north to south following the climatic zones (Harrison and Jackson, 1958; El-Sarrag et al., 1992; El-Sarrag, 1977; Hepburn and Radloff, 1998): desert, semi-desert, dry-savannah, wet-savannah and forests (Tab. I, Fig. 2). The desert regions cover about one third of the entire country with only very light and irregular rain fall (0-50 $\mathrm{mm}$ per year). There is no vegetation, except in desert valleys and adjacent to the River Nile. Further south, the semi-desert region is richer in vegetation due to $50-300 \mathrm{~mm}$ rainfall per year, followed by the dry savannah region with an annual rainfall of 300$500 \mathrm{~mm}$ per year and a dry season of four to six months (starting in April). The wet savannah region includes Bahr Elarab, Jebel Marra, Nuba Mountains, Ingessana Hills and White Nile tributaries with annual rainfalls of up to $1000 \mathrm{~mm}$. Finally, forests form the most southern vegetation belt in the Sudan with annual rainfalls of up to $1600 \mathrm{~mm}$ resulting in thick vegetation.

The biogeographical distribution of $\mathrm{A}$ and O lineages of honeybees fits well with the climatic differentiation of Sudan. The O lineage was primarily observed in the dry regions, whereas the A lineage is more typical of the tropical climate (Garnery et al., 1993, 1995; Franck et al., 1998, 2000a, b, 2001). Even within the lineage A haplotypes of South and South-West Sudan, the ecosystem classification seems to hold. Type $\mathrm{A}_{1}$ honeybees primarily occurred in the wet savannahs and forests regions, the typical biome for A. m. adansonii. In contrast, the haplotype $\mathrm{A}_{4}$ was only observed in dry savannahs, the typical biome of A. m. scutellata (Ruttner, 1988). In general, the transitional zones between African honey- bee subspecies are associated with transitions between ecosystems (Hepburn and Radloff, 1997) which nicely fits with the transition from the A- to the O lineage in Sudan.

According to our analyses, the honeybees in Sudan appear to be composed of two lineages, $\mathrm{A}$ and $\mathrm{O}$, with different haplotypes $\mathrm{O}_{1}$, $\mathrm{O}_{1}{ }^{\prime}, \mathrm{A}_{1}, \mathrm{~A}_{4}, \mathrm{~A}_{8}, \mathrm{~A}_{13}$ rather than one lineage (Y). Clearly, honeybees of the dry regions are genetically more similar to A. m. lamarckii, whereas the honeybees of the wet regions are more similar to A. m. adansonii. Hence the honeybees of Sudan may not represent a single well defined subspecies but may rather reflect a mix of $\mathrm{O}$ and $\mathrm{A}$ lineage populations with a strong difference between bees in the North and in the South. This may explain the problems experienced in morphometrical studies where morphoclusters were often incoherent and did not result in concise classifications (Hepburn and Radloff, 1996, 1997).

In addition, we found local evidence of introgression of commercially imported honeybee stock. Although this is of principle concern from a conservation point of view, it seems to have had no far reaching impact yet, because it was confined only to the few commercial apiaries sampled. Given the lack of European haplotypes in the wild colonies, in spite of repeated and massive introductions over many decades (Mogga, 1988; ElSarrag and Nagi, 1989), this may be another case where natural selection favours locally adapted $A$. mellifera and purges maladapted imported stock from the population (Moritz et al., 2005).

\section{ACKNOWLEDGEMENTS}

Research was funded by the EC within the FP 6 Integrated Project "ALARM" (Assessing LArge scale environmental Risks for biodiversity with tested Methods; GOCE-CT-2003-506675 (Settele et al., 2005) and the Strategic Research Project BEE SHOP (Bees in Europe and Sustainable Honey Production) (RFAM). Financial support was also granted by the Deutsche Akademische Austauschdienst and the National Centre for Research, Khartoum, Sudan (MAAE). 


\section{Caractérisation des abeilles (Apis mellifera) du Soudan par l'ADN mitochondrial.}

\section{Apis mellifera jemenitica / ADN mitochondrial / race / discrimination / biogéographie / Soudan}

Zusammenfassung - Mitochondrielle Unter-
scheidung der Honigbienen (Apis mellifera) Sudans. Die Klassifizierung der Honigbienen (Apis mellifera) Sudans wird kontrovers diskutiert. Sie wurden zunächst als $A$. m. nubica, dann als $A$. $m$. jemenitica und schließlich als Gruppe heterogener Morphotypen klassifiziert. Die Honigbienen Sudans sind von einer Reihe verschiedenster Bienenrassen umgeben, die unterschiedlichen biogeographischen Linien angehören: Im Norden die O-Linie, im Osten die Y-Linie und im Süden und Westen die A-Linie. Angesichts dieser großen Variation, sollten mtDNA Polymorphismen ein ideales Werkzeug sein, um den Subspezies-Status der sudanesischen Honigbienen zu überprüfen. Die Größe des Landes und die extreme Ökosystemvielfalt stellt günstige Vorbedingungen für eine große Honigbienenvielfalt. Wir nutzen mtDNA-Polymorphismen, um die SubspeziesZugehörigkeit $\mathrm{zu}$ bestimmen und $\mathrm{zu}$ prüfen, inwieweit durch Bienenimporte und Imkerei nichtendemische Rassen in wilde Populationen eingedrungen sind.

Arbeiterinnen wurden von 47 wilden und 28 imkerlich bewirtschafteten Völkern an verschiedenen Standorten (von Wüste bis Regenwald) im Sudan gesammelt (Abb. 1). DNA wurde extrahiert und die mtDNA mit PCR Methoden amplifiziert. Die PCR Pordukte wurden mit Dra I restringiert und die Restriktionsmuster im Acrylamidgel visualisiert (Abb. 2). Alle Haplotypen wurden zur Bestätigung des jeweiligen mtDNA-Typus sequenziert.

Wir fanden keine Y-Haplotypen, die als typisch für $A$. $m$. jemenitica gelten. Statt dessen fanden wir sieben verschiedene Haplotypen aus der A- und Olinie (Abb. 1) und A. m. jemenitica scheint im Sudan keine häufige subspezies zu sein. Die hohe Diversität scheint in erster Linie durch die sehr unterschiedlichen Ökosystemtypen des Landes bestimmt zu sein, da die Haplotypen eng an die klimatischen Bedingungen gekoppelt sind. Die Bienen der feuchteren Klimate zeigten den $\mathrm{A}_{1}$ und den $\mathrm{A}_{4}$ Typus (Abb.1) während Bienen aus den trockeneren $\mathrm{Ge}-$ genden der O-Linie $\left(\mathrm{O}_{1}\right.$ und $\left.\mathrm{O}_{1}{ }^{\prime}\right)$ zugehören. Der $\mathrm{C}_{2}$-Haplotyp kam nur in einer Imkerei mit rezent importierten Bienenköniginnen europäischer Herkunft vor. In den Wildpopulationen konnten keine Hinweise auf nichtendemische Honigbienen gefunden werden.

Die Reklassifikation der sudanesischen Honigbienen hat weitreichende Konsequenzen für die Interpretation der Biogeographie von A. mellifera im Maghreb und Mashriq. Die Häufigkeit des O-Typus im Sudan bestätigt erneut, dass im Nordosten Afri- kas drei verschiedene biogeographische Linien zusammentreffen. Die These von Ruttner et al. (1978), der Nordosten Afrikas stelle eine Region mit hoher Variabilität dar, findet somit erneut Unterstützung.

Apis mellifera jemenitica / Bienenrasse / mitochondrielle DNA / Sudan / Biogeographie

\section{REFERENCES}

Amssalu B., Nuru A., Radloff S.E., Hepburn H.R. (2004) Multivariate morphometric analysis of honeybees (Apis mellifera) in the Ethiopian region, Apidologie 35, 71-81.

Arias M.C., Sheppard W.S. (1996) Molecular phylogenetics of honeybee subspecies (Apis mellifera L.), Mol. Phylogenet. Evol. 5, 557-566.

Baldensperger P.J. (1932) Variétés d'abeilles en Afrique du nord, 5th Congr. Int. Entomol. Paris, pp. 829-839.

Cockerell T.D.A. (1906) New rocky mountain bees, and other notes, Can. Entomol. 38, 160-166.

Cornuet J.M., Garnery L. (1991) Mitochondrial DNA variability in honeybees and its phylogeographic implications, Apidologie 22, 627-642.

El-Sarrag M.S.A. (1977) Morphometrical and Biological Studies on Sudanese Honeybees Apis mellifera (Hymenoptera: Apidae), Ph.D. Thesis, Cairo University, Egypt.

El-Sarrag M.S.A., Nagi S.K.A. (1989) Studies on some factors affecting mating of queen honeybees in Khartoum area Sudan, Proc. 4 Int. Conf. Apic. Trop. Climates, Cairo, pp. 20-24.

El-Sarrag M.S.A., Saeed A.A., Hussien M.A. (1992) Morphometrical study on Sudanese Honeybees, J. King. Saud. Univ. Agric. Sci. 1, 99-100.

Engel M.S. (1999) The taxonomy of recent and fossil honey bees (Hymenoptera: Apidae; Apis), J. Hymenoptera Res. 8, 165-196.

Franck P., Garnery L., Solignac M., Cornuet J.M. (1998) The origin of west European subspecies of honeybees (Apis mellifera): New insights from microsatellite and mitochondrial data, Evolution 52, 1119-1134.

Franck P., Garnery L., Celebrano G., Solignac M. (2000a) Hybrid origins of the Italian honeybees, Apis mellifera ligustica and A. m. sicula, Mol. Ecol. 9, 907-923.

Franck P., Garnery L., Solignac M., Cornuet J.M. (2000b) Molecular confirmation of a fourth lineage in honeybees from Middle-East, Apidologie $31,167-180$.

Franck P., Garnery L., Loiseau A., Oldroyd B.P., Hepburn H.R., Solignac M., Cornuet J.M. (2001) Genetic diversity of the honeybee in Africa: microsatellite and mitochondrial data, Heredity 86, 420-430. 
Garnery L., Cornuet J.M., Solignac M. (1992) Evolutionary history of the honeybee Apis mellifera inferred from mitochondrial DNA analysis, Mol. Ecol. 1, 145-154.

Garnery L., Solignac M., Celebrano G., Cornuet J.M. (1993) A simple test using restricted PCRamplified mitochondrial DNA to study the genetic structure of Apis mellifera L., Experientia 49, 1016-1021.

Garnery L., Mosshine E.H., Oldroyd B.P., Cornuet J.M. (1995) Mitochondrial DNA variation in Moroccan and Spanish honey bee populations, Mol. Ecol. 4, 465-471.

Gasse F.R., Tehet A., Durand A., Gilbert E., Fontes J.C. (1990) The arid-humid transition in the Sahara and Sahel during the last glaciation, Nature 346, 141-146.

Harrison M.N., Jackson J.K. (1958) Ecological Classification of Vegetation Of Sudan, Bulletin 2, 1-45, Forest Department, Khartoum.

Hepburn H.R., Radloff S.E. (1996) Morphometric and pheromonal analyses of Apis mellifera L. along a transect from the Sahara to the Pyrenees, Apidologie 27, 35-45.

Hepburn H.R., Radloff S.E. (1997) Biogeographical correlates of population variance in the honeybees (Apis mellifera L.) of Africa, Apidologie 28, 243258.

Hepburn H.R., Radloff S.E. (1998) Honeybees of Africa, Springer-Verlag, Berlin.

Hooghiemstra H., Stalling H., Agwu C.O.C., Dupont L.M. (1992) Vegetation and climatic changes at the northern fringe of the Sahara 2500005000 years BP, Rev. Palaeobot. Palynol. 74, 1-53.

Maa T.C. (1953) An inquiry into the systematics of the tribus Apidini or honeybees (Hymenoptera), Treubia 21, 525-640.

Meixner M.D., Arias M.C., Sheppard W.S. (2000) Mitochondrial DNA polymorphisms in honey bee subspecies from Kenya, Apidologie 31, 181-190.

Mogga J.B. (1988) The Taxonomy and Geographical Variability of the Honeybee Apis mellifera L. (Hymenoptera: Apidae) in Sudan, MSc. Thesis, University of Khartoum, Khartoum.

Moritz R.F.A., Cornuet J.M., Kryger P., Garnery L., Hepburn H.R. (1994) Mitochondrial DNA variability in South African honeybees (Apis mellifera L.), Apidologie 25, 169-178.

Moritz R.F.A., Beye M., Hepburn H.R. (1998) Estimating the contribution of laying workers to population fitness in African honeybees (Apis mellifera) with molecular markers, Insectes Soc. 45 , 277-287.

Moritz R.F.A., Härtel S., Neumann P. (2005) Global invasions of the western honey bee (Apis mellifera) and the consequences for biodiversity, Ecoscience 12, 289-301.
Potts R., Behrensmeyer A.K. (1992) Late Cenozoic terrestrial ecosystems, in: Behrensmeyer A.K., Damuth J.D., Di Michele W.A. et al. (Eds.), Terrestrial Ecosystems Through Time: Evolutionary Paleoecology of Terrestrial Plants and Animals, University of Chicago Press, Chicago, pp. 419-541.

Ritchie J.C. (1994) Holocene pollen spectra from Oyo, north northwestern Sudan: problems of interpretation in a hyperarid environment, The Holocene 4, 9-15.

Rudloff W. (1981) World Climate, Wissenschaftliche Verlagsgesellschaft, Stuttgart.

Ruttner F. (1975) African races of honeybees, Proc. 25th Int. Beekeep. Congr. Bucharest, Apimondia, pp. 325-362.

Ruttner F. (1988) Biogeography and Taxonomy of Honeybees, Springer, Berlin.

Ruttner F. (1992) Naturgeschichte der Honigbienen, Ehrenwirth, München.

Ruttner F., Tassencourt L., Louveaux J. (1978) Biometrical-statistical analysis of the geographic variability of Apis mellifera L., Apidologie 9, 363381.

Settele J., Hammen V., Hulme P., Karlson U., Klotz S., Kotarac M., Kunin W., Marion G., O’Connor M., Petanidou T., Peterson K., Potts S., Pritchard H., Pysek P., Rounsevell M., Spangenberg J., SteffanDewenter I., Sykes M., Vighi M., Zobel M., Kühn I. (2005) ALARM-Assessing Large-scale environmental Risks for biodiversity with tested Methods, Gaia 14, 69-72.

Smith D.R. (1991) Diversity in the Genus Apis, Westview Press, Boulder, CO.

Smith D.R., Brown W.M. (1988) Polymorphisms in mitochondrial DNA of European and Africanized honeybees (Apis mellifera), Experientia 44, $257-$ 260.

Smith F.G. (1961) The races of honeybees in Africa, Bee World 42, 255-260.

Van Chi-Bonnardel R. (Ed.) (1973) The Atlas of Africa, Éditions Jeune Afrique, Paris.

Walsh P.S., Metzger D.A., Higuchi R. (1991) Chelex 100 as medium for simple extraction of DNA for PCR-based typing from forensic material, Biotechniques 10, 506-513.

Walter H. (1976) Vegetationszonen und Klima, Ulmer, Stuttgart.

Whitfield C.W., Behura S.K., Berlocher S.H., Clark A.G., Johnston J.S., Sheppard W.S. Smith D.R., Suarez A.V., Weaver D., Tsutsui N.D. (2006) Thrice out of Africa: ancient and recent expansions of the honeybee Apis mellifera, Science 314, 642-645. 